\title{
Ottawa Model of Implementation Leadership and Implementation Leadership Scale: mapping concepts for developing and evaluating theory-based leadership interventions [Corrigendum]
}

\author{
Gifford W, Graham ID, Ehrhart MG, Davies BL, Aarons GA. \\ Journal of Healthcare Leadership. 2017;9:15-23.
}

Page 15, the author affiliation section is incorrect. The correct author affiliations are shown below.

\author{
Wendy Gifford ${ }^{1,2}$ \\ Ian D Graham ${ }^{1,3,4}$ \\ Mark G Ehrhart ${ }^{5}$ \\ Barbara L Davies ${ }^{1,2}$ \\ Gregory A Aarons ${ }^{6,7}$
}

'School of Nursing, Faculty of Health Sciences, University of Ottawa, ON, Canada; ${ }^{2}$ Nursing Best Practice Research Center, University of Ottawa, ON, Canada; ${ }^{3}$ Centre for Practice-Changing Research, Ottawa Hospital Research Institute, Ottawa, ON, Canada; ${ }^{4}$ School of Epidemiology, Public Health and Preventive Medicine, Facility of Medicine, University of Ottawa, Ottawa, ON, Canada; ${ }^{5}$ Department of Psychology, San Diego State University, San Diego, CA, USA; ${ }^{6}$ Department of Psychiatry, University of California, San Diego, La Jolla, CA, USA; ${ }^{7}$ Child and

Adolescent Services Research Center, San Diego, CA, USA

The Journal of Healthcare Leadership is an international, peer-reviewed, open access journal focusing on leadership for the health profession. The journal is committed to the rapid publication of research focusing on but not limited to: Healthcare policy and law; Theoretical and practical aspects of healthcare delivery; Interactions between healthcare and society and evidence-based practices;

Interdisciplinary decision-making; Philosophical and ethical issues; Hazard management; Research and opinion for health leadership; Leadership assessment. The manuscript management system is completely online and includes a very quick and fair peer-review system. Visit http://www.dovepress.com/ testimonials.php to read real quotes from published authors. 